\title{
Effectiveness of enrofloxacin for the treatment of experimentally-induced bovine anaplasmosis
}

\author{
Eficácia da enrofloxacina no tratamento da anaplasmose bovina experimental
}

Elias Jorge Facury-Filho'; Antônio Último de Carvalho' ${ }^{1}$; Paulo Marcos Ferreira ${ }^{1}$; Marcelo Fonseca Moura ${ }^{1}$; Bethania Campos Apolinário ${ }^{1}$; Leandro de Paula Henrique Santos'; Múcio Flávio Barbosa Ribeiro ${ }^{2 *}$

${ }^{1}$ Department of Veterinary Clinics and Surgery, Veterinary School of Minas Gerais, Federal University of Minas Gerais - UFMG

${ }^{2}$ Department of Parasitology, Institute of Biological Science - ICB, Federal University of Minas Gerais - UFMG

Received April 25, 2011

Accepted December 06, 2011

\begin{abstract}
Four groups of six Holstein calves were inoculated with $3.6 \times 10^{7}$ erythrocytes parasitized with Anaplasma marginale. The criteria for treatment of calves were increasing $A$. marginale rickettsemia and $30 \%$ reduction of baseline packed cell volume (PCV) of each animal. Group 1 (G1) received $7.5 \mathrm{mg} \cdot \mathrm{kg}^{-1}$ of enrofloxacin in a single dose; Group 2 (G2) $7.5 \mathrm{mg} \cdot \mathrm{kg}^{-1}$ of enrofloxacin twice every three days; Group 3 (G3) $20 \mathrm{mg} \cdot \mathrm{kg}^{-1}$ of long-acting oxytetracycline in a single dose; and Group 4 (G4) a single dose of PBS. Physical examinations, blood smears and PCV were performed daily. On day treatment, G1, G2 and G3 animals had a mean rickettsemia of 17, 23 and 12\%, respectively. At 2 days after treatment (DAT) G1 and G2 animals showed a significant reduction of rickettsemia $(\mathrm{p}<0.05)$ compared to G3. G3 animals had high rates of rickettsemia in the first 2 DAT and a slow decrease until stabilization on 9 DAT. The mean PCV in G1 and G2 increased and stabilized after 7 and 8 DAT, respectively. PCV stabilization was achieved in G3 at 13 DAT. Both enrofloxacin and oxytetracycline were effective for the treatment of anaplasmosis, but enrofloxacin was faster reduction of rickettsemia and PCV recuperation $(\mathrm{p}<0.05)$ compared to oxytetracycline
\end{abstract}

Keywords: Anaplasma marginale, enrofloxacin, treatment.

\section{Resumo}

Quatro grupos de seis bezerros da raça Holandesa foram inoculados com 3,6 × 107 eritrócitos parasitados com Anaplasma marginale. Os critérios para o tratamento dos bezerros foram aumento da rickettsemia do $A$. marginale e redução de 30\% do valor basal de volume globular (VG) de cada animal. O Grupo 1 (G1) recebeu $7,5 \mathrm{mg} \cdot \mathrm{kg}^{-1} \mathrm{de}$ enrofloxacina em dose única; o Grupo 2 (G2), $7,5 \mathrm{mg} \cdot \mathrm{kg}^{-1}$ de enrofloxacina duas vezes a cada três dias; o Grupo 3 (G3), $20 \mathrm{mg} \cdot \mathrm{kg}^{-1}$ de oxitetraciclina de longa ação em dose única; e o Grupo 4 (G4) uma única dose de PBS. Exames físicos, esfregaço sanguíneo e VG foram realizadas diariamente. No dia do tratamento, os animais G1, G2 e G3 apresentaram rickettsemia média de 17, 23 e 12\%, respectivamente. Nos primeiros 2 dias após o tratamento (DAT) os animais do G1 e G2 mostraram uma redução significativa de rickettsemia $(\mathrm{p}<0,05)$ em relação ao G3. Animais do G3 tiveram altas taxas de rickettsemia nos 2 DAT e uma diminuiçáo lenta até à estabilização em 9 de DAT. O VG médio no G1 e G2 aumentou e estabilizou após 7 e 8 DAT, respectivamente. A estabilização do VG do G3 foi aos 13 DAT. A enrofloxacina e a oxitetraciclina foram efetivas no tratamento da anaplasmose, mas a enrofloxacina apresentou redução da rickettsemia e recuperação do VG $(\mathrm{p}<0,05)$ mais rápida em comparação com oxitetraciclina.

Palavras-chave: Anaplasma marginale, enrofloxacina, tratamento.

\footnotetext{
${ }^{*}$ Corresponding author: Múcio Flávio Barbosa Ribeiro Departamento de Parasitologia, Instituto de Ciências Biológicas - ICB, Universidade Federal de Minas Gerais - UFMG, Belo Horizonte, Av. Antônio Carlos, 6627, Pampulha, Belo Horizonte, MG, Brazil e-mail: muciobr@icb.ufmg.br
} 


\section{Introduction}

Bovine anaplasmosis is caused by the intraerythrocytic rickettsia Anaplasma marginale and is an endemic condition in tropical and subtropical areas. Ticks are the biological vector, but transmission may also occur mechanically by mosquitoes and bloodsucking flies (YERUHAM; BRAVERMAN, 1981). In endemic areas, calves are infected during the first months of life. Acute infections develop into a clinical disease characterized by anemia and weight loss (CORRIER; GUZMAN, 1977; RIBEIRO; REIS, 1981), and death can occur in 36\% (PALMER, 1989). Animals that survive the clinical disease remain persistent carriers with low rickettsemia. They may be a source of infection for other susceptible animals that become infected through mechanical and biological vectors (SCHILF, 1971). Animal susceptibility increases with age, and younger animals are more resistant to the first infection, and have less severe clinical symptoms (ROBY et al., 1961; JONES et al., 1968).

Over the past 30 years no new drugs have been developed for the specific treatment of bovine anaplasmosis. Oxytetracycline and imidocarb drugs are still commonly used, but some studies have investigated the use of enrofloxacin for the treatment of animals with clinical manifestations (GUGLIELMONE et al., 1996; COETZEE; APLEY, 2006)

This study aimed to assess the effectiveness of enrofloxacin (Kinetomax ${ }^{\otimes}$ Bayer) for the treatment of calves with experimentallyinduced acute anaplasmosis.

\section{Materials and Methods}

Twenty-four male Friesian calves reared from birth in a tie-stall barn and undergoing weekly sprayings with deltametrine (Butox, Quimio) to prevent tick and fly bites were used.

Before the beginning of the experiment, blood samples of calves were collected weekly for a blood smear-based detection of A. marginale using Giemsa staining and packed cell volumes (PCVs) were determined by microhematocrit technique. Anti- $A$. marginale, anti-Babesia bovis and anti-B. bigemina antibodies were detected using indirect fluorescent antibody test (IFAT) to ensure that the study calves were not infected with hemoparasites.

The calves aged 90 days were randomly divided into four groups of six calves each. All animals were inoculated intravenously with $3.6 \times 10^{7}$ erythrocytes parasitized with UFMG2 isolate, a highly virulent sample of $A$. marginale (Genbank no EU676175) causing high morbidity and mortality rates in susceptible cattle (BASTOS et al., 2010).

The criteria for treatment of calves were increasing $A$. marginale rickettsemia and 30\% reduction of baseline PCV, determined individually before inoculation. Rickettsemia was assessed through Giemsa-stained peripheral blood smears and the percentage of parasitized erythrocytes was determined by dividing the number of infected erythrocytes in 40 fields by the total number of erythrocytes in 40 fields at $100 \times$ oil immersion (IICA, 1987). The day treatment was given was Day zero. Group 1 (G1) received $7.5 \mathrm{mg} \cdot \mathrm{kg}^{-1}$ of enrofloxacin in a single dose while Group 2 (G2) received $7.5 \mathrm{mg} \cdot \mathrm{kg}^{-1}$ of enrofloxacin twice every three days;
Group 3 (G3) received $20 \mathrm{mg} \cdot \mathrm{kg}^{-1}$ of long-acting oxytetracycline (Tetrabac ${ }^{\oplus}$, Bayer) in a single dose; and Group 4 (G4) was used as treatment control and received $1 \mathrm{~mL} / 10 \mathrm{~kg}$ of a saline solution in a single dose. G4 animals that presented clinical symptoms of acute anaplasmosis were treated with oxytetracycline and medical support (hydration and blood transfusions) to prevent death.

Throughout the experiment, the animals were physically examined and monitored daily (rectal temperature, PCV and rickettsemia) until 27 days after treatment (DAT).

All experimental procedures were approved by the Animal Experimentation Ethics Committee (CETEA/UFMG; protocol number 146/2008).

\section{Statistical analyses}

The statistical design was a completely randomized split-plot arrangement with 6 repetitions per group and time as subplots. The means of the parameters studied were analyzed using the Student-Newman-Keuls (SNK) test.

Mean \pm SEM (standard error of the mean) was calculated for all parameters. Statistical significance was set a priori as $\mathrm{p} \leq 0.05$.

\section{Results}

\section{Rickettsemia}

All animals inoculated with $A$. marginale UFMG2 isolate showed infected erythrocytes on stained blood smears between 20 to $27(21.04 \pm 1.51)$ days after inoculation (DAI). On treatment day (Day 0) the animals in G1, G2 and G3, presented mean rickettsemia of 17, 23 and 12\%, respectively. Animals in G1 and G2 showed rising rickettsemia levels in the first 24 hours after treatment. Then, rickettsemia had a rapid decline and was significantly lower $(\mathrm{p}<0.05)$ than that seen in G3 by 9 DAT. The comparison of G1 and G2 showed no significant difference ( $p>0.05)$ in the reduction of rickettsemia. G3 animals had high rates of rickettsemia in the first 2 DAT (Figure 1). A slow progressive reduction was seen later by 9 DAT when rickettsemia levels stabilized. After 10 DAT there were no significant differences in the pattern of rickettsemia in the three experimental groups (Figure 1).

Animals from G4 showed constantly increasing $A$. marginale rickettsemia. When rickettsemia reached $>40 \%$ and was associated with severe anemia $(\mathrm{PCV}<13 \%)$, these animals were removed from the experiment to receive specific treatment.

\section{Packed cell volume}

The animals in G1, G2 and G3 were treated when their mean PCV was 18.3, 20.7 and 22.8\%, respectively. PCVs are shown in Figure 2.

Animals from G1 had the greatest reductions in PCV after treatment. They recovered rapidly and sharply after 3 DAT and reached a PCV equal to or greater than baseline on 8 DAT. After 14 DAT PCV values reached normal levels $(\geq 24 \%)$. 


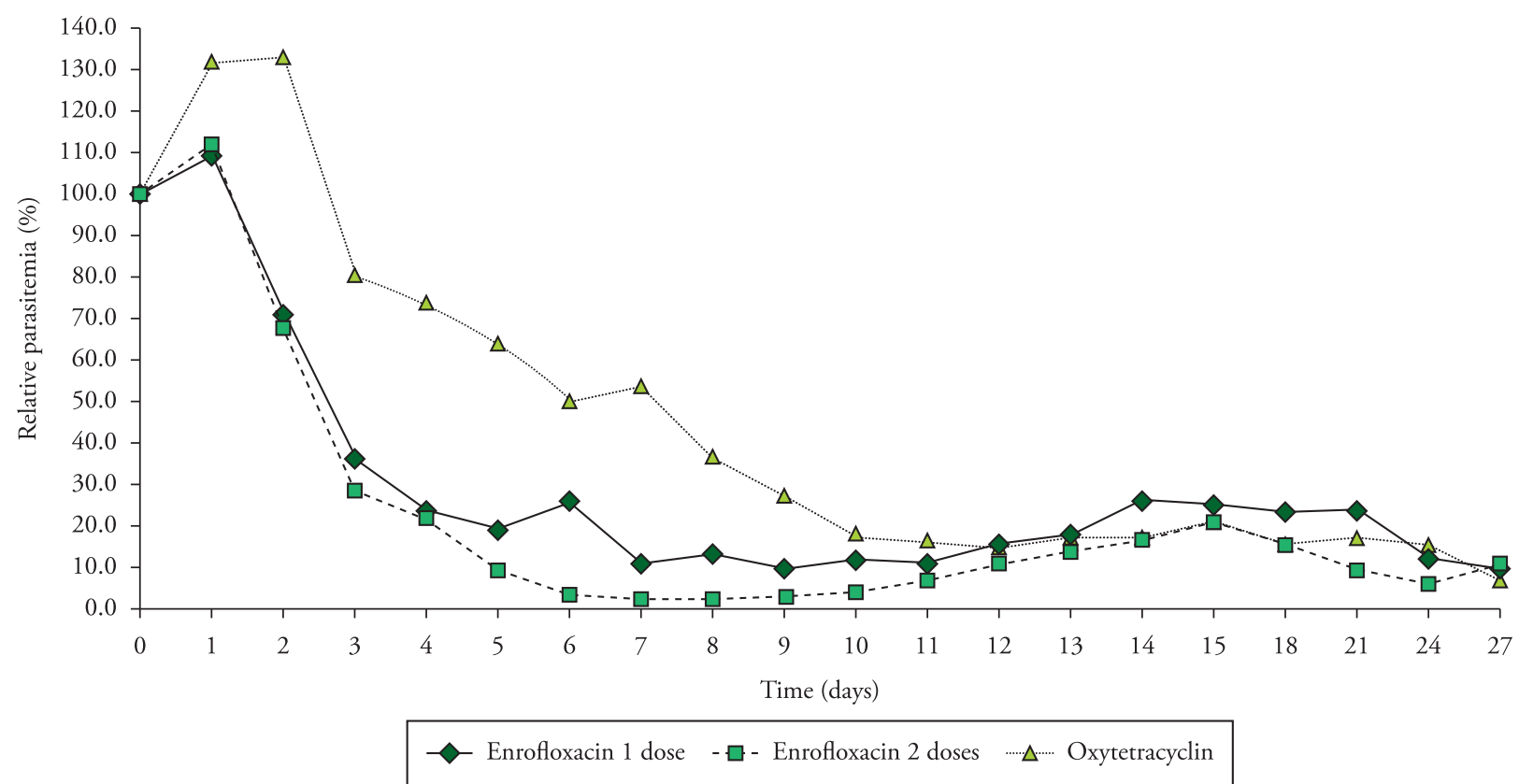

Figure 1. Relative Anaplasma marginale rickettsemia in experimentally infected calves treated with enrofloxacin or oxytetracycline.

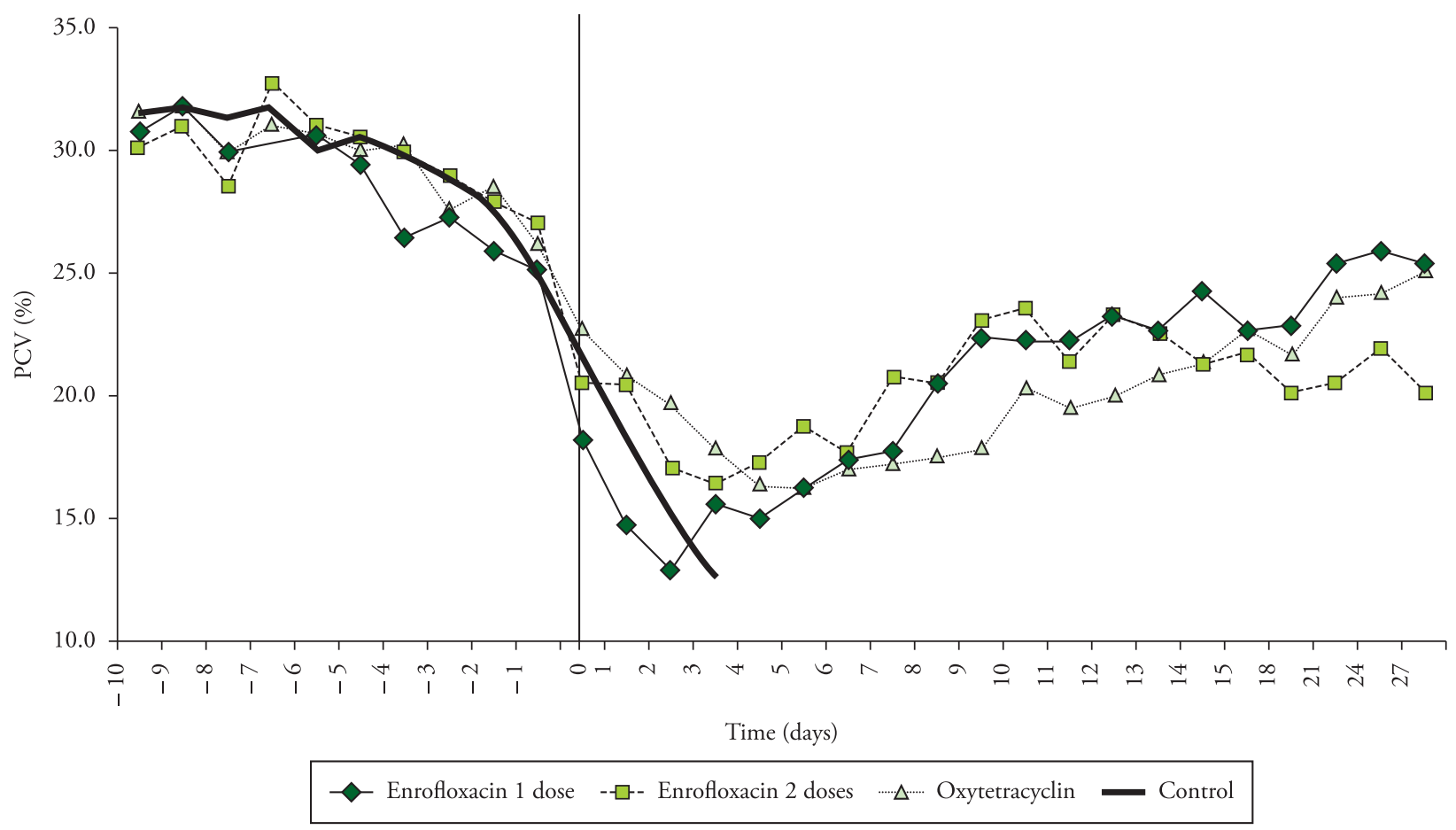

Figure 2. PCV changes in calves with experimentally induced Anaplasma marginale infection after treatment with enrofloxacin or oxytetracycline.

The animals in G2 had the smallest reductions of PCV. On 7 DAT their PCV values were equal to those at baseline. However, these animals did not show PCV $\geq 24 \%$ at the end of the experiment (27 DAT).

After treatment with oxytetracycline (G3), PCVs continued to decrease until 5 DAT. Then there was a progressive recovery and normal PCV values $(\geq 24 \%)$ were reached on 21 DAT.

\section{Clinical examination}

All animals had clinical signs of anaplasmosis including apathy, decreased food intake, pale mucous membranes, fever, increased heart and respiratory rates and ruminal hypomotility.

The body temperatures of animals in G1, G2 and G3 are shown in Table 1. All animals treated with enrofloxacin (G1 and G2) had 
Table 1. Body temperature of calves with Anaplasma marginale experimentally-induced anaplasmosis receiving treatment with enrofloxacin or oxytetracycline.

\begin{tabular}{|c|c|c|c|c|c|c|c|c|c|c|c|c|c|c|c|c|c|c|c|c|}
\hline \multirow[t]{2}{*}{ Group } & \multicolumn{20}{|c|}{ Body temperature $\left({ }^{\circ} \mathrm{C}\right) /$ moments (days) } \\
\hline & $\mathbf{0}$ & 1 & 2 & 3 & 4 & 5 & 6 & 7 & 8 & 9 & 10 & 11 & 12 & 13 & 14 & 15 & 18 & 21 & 24 & 27 \\
\hline 1 & $\begin{array}{c}\mathrm{Ab} \\
39.7\end{array}$ & $\begin{array}{c}\mathrm{Aa} \\
40.2\end{array}$ & $\begin{array}{c}\mathrm{Ab} \\
39.7\end{array}$ & $\begin{array}{c}\mathrm{Ab} \\
39.5\end{array}$ & $\begin{array}{c}\text { Ac } \\
39.0\end{array}$ & $\begin{array}{c}\text { Ac } \\
39.0\end{array}$ & $\begin{array}{c}\mathrm{Bc} \\
38.6\end{array}$ & $\begin{array}{c}\text { Ac } \\
39.2\end{array}$ & $\begin{array}{c}\text { Ac } \\
38.7\end{array}$ & $\begin{array}{c}\text { Ac } \\
38.9\end{array}$ & $\begin{array}{c}\text { Ac } \\
38.9\end{array}$ & $\begin{array}{c}\text { Ac } \\
38.9\end{array}$ & $\begin{array}{c}\mathrm{Bc} \\
38.4\end{array}$ & $\begin{array}{c}\text { Ac } \\
38.9\end{array}$ & $\begin{array}{c}\text { Ac } \\
39.0\end{array}$ & $\begin{array}{c}\text { Ac } \\
39.0\end{array}$ & $\begin{array}{c}\mathrm{Ab} \\
39.4\end{array}$ & $\begin{array}{c}\text { Ac } \\
39.1\end{array}$ & $\begin{array}{c}\text { Ac } \\
38.8\end{array}$ & $\begin{array}{c}\text { Ac } \\
39.0\end{array}$ \\
\hline 2 & $\begin{array}{c}\mathrm{Ab} \\
39.5\end{array}$ & $\begin{array}{c}\mathrm{Aa} \\
40.5\end{array}$ & $\begin{array}{c}\mathrm{Bb} \\
39.2\end{array}$ & $\begin{array}{c}\mathrm{Ab} \\
39.3\end{array}$ & $\begin{array}{c}\mathrm{Ab} \\
39.4\end{array}$ & $\begin{array}{c}\text { Ac } \\
39.0\end{array}$ & $\begin{array}{c}\text { Ac } \\
38.8\end{array}$ & $\begin{array}{c}\mathrm{Bc} \\
38.6\end{array}$ & $\begin{array}{c}\text { Ac } \\
38.6\end{array}$ & $\begin{array}{c}\mathrm{Ac} \\
38.7\end{array}$ & $\begin{array}{c}\text { Ac } \\
38.8\end{array}$ & $\begin{array}{c}\text { Ac } \\
38.8\end{array}$ & $\begin{array}{c}\text { Ac } \\
38.8\end{array}$ & $\begin{array}{c}\text { Ac } \\
38.8\end{array}$ & $\begin{array}{c}\mathrm{Bc} \\
38.3\end{array}$ & $\begin{array}{c}\text { Ac } \\
39.1\end{array}$ & $\begin{array}{c}\mathrm{Bc} \\
38.8\end{array}$ & $\begin{array}{c}\text { Ac } \\
39.0\end{array}$ & $\begin{array}{c}\mathrm{Ab} \\
39.1\end{array}$ & $\begin{array}{c}\text { Ac } \\
38.8\end{array}$ \\
\hline 3 & $\begin{array}{c}\mathrm{Aa} \\
39.4\end{array}$ & $\begin{array}{c}\mathrm{Ba} \\
39.4\end{array}$ & $\begin{array}{c}\mathrm{Aa} \\
39.7\end{array}$ & $\begin{array}{c}\mathrm{Aa} \\
39.3\end{array}$ & $\begin{array}{c}\mathrm{Aa} \\
39.2\end{array}$ & $\begin{array}{c}\mathrm{Aa} \\
39.3\end{array}$ & $\begin{array}{c}\mathrm{Aa} \\
39.2\end{array}$ & $\begin{array}{c}\mathrm{Aa} \\
39.4\end{array}$ & $\begin{array}{c}\mathrm{Aa} \\
39.1\end{array}$ & $\begin{array}{c}\mathrm{Aa} \\
39.1\end{array}$ & $\begin{array}{c}\mathrm{Aa} \\
39.3\end{array}$ & $\begin{array}{c}\mathrm{Ab} \\
38.8\end{array}$ & $\begin{array}{c}\mathrm{Aa} \\
39.1\end{array}$ & $\begin{array}{c}\mathrm{Ab} \\
38.9\end{array}$ & $\begin{array}{c}\mathrm{Ab} \\
38.8\end{array}$ & $\begin{array}{c}\mathrm{Ab} \\
38.8\end{array}$ & $\begin{array}{c}\mathrm{Bb} \\
38.7\end{array}$ & $\begin{array}{c}\mathrm{Bb} \\
38.7\end{array}$ & $\begin{array}{c}\mathrm{Aa} \\
39.1\end{array}$ & $\begin{array}{c}\mathrm{Ab} \\
38.5\end{array}$ \\
\hline 6 & $\begin{array}{c}\text { B } \\
38.5\end{array}$ & $\begin{array}{c}\mathrm{C} \\
38.5\end{array}$ & $\begin{array}{c}C \\
38.4\end{array}$ & $\begin{array}{c}\text { B } \\
38.5\end{array}$ & $\begin{array}{c}\text { B } \\
38.2\end{array}$ & $\begin{array}{c}\text { B } \\
38.3\end{array}$ & $\begin{array}{c}\text { B } \\
38.4\end{array}$ & $\begin{array}{c}\text { B } \\
38.3\end{array}$ & $\begin{array}{c}\text { A } \\
38.6\end{array}$ & $\begin{array}{c}\text { B } \\
38.2\end{array}$ & $\begin{array}{c}\text { B } \\
38.4\end{array}$ & $\begin{array}{c}\text { A } \\
38.4\end{array}$ & $\begin{array}{c}\text { B } \\
38.4\end{array}$ & $\begin{array}{c}\text { A } \\
38.5\end{array}$ & $\begin{array}{c}\text { B } \\
38.4\end{array}$ & $\begin{array}{c}\text { B } \\
38.2\end{array}$ & $\begin{array}{c}\text { B } \\
38.3\end{array}$ & $\begin{array}{c}\text { B } \\
38.6\end{array}$ & $\begin{array}{c}\text { A } \\
38.8\end{array}$ & $\begin{array}{c}\text { A } \\
38.7\end{array}$ \\
\hline
\end{tabular}

Different letters, uppercase and lowercase letters in the column line indicate statistically significant difference $(\mathrm{p}<0.05)$.

body temperatures that were back to normal ranges at 4 DAT; however, in the G3, normal temperatures were seen only on 11 DAT (Table 1).

There were no significant differences in respiratory and heart rates (data not shown) between the groups.

\section{Discussion}

All animals inoculated with $A$. marginale UFMG2 isolate became ill and had clinical symptoms of anaplasmosis. Animals in G4 required treatment to prevent death. These results suggest the highly pathogenic nature of the sample used.

This study sought to reproduce common clinical scenarios of bovine anaplasmosis in the field where animals show patent rickettsemia and severe anemia. In endemic areas, treatment is not aimed to eliminate $A$. marginale but reduce clinical symptoms and restore normal physiological functioning of animals.

For the treatment of anaplasmosis and other rickettsia infections oxytetracycline is the drug of choice. However, it has rickettsiostatic effects associated with its mechanism of action of protein synthesis inhibition (SCHOLAR; PRATT, 2000). Animals infected with $A$. marginale that are treated with oxytetracycline present unchanged rickettsemia or even increased levels for 2 to 3 days. Coetzee et al. (2009) using electron microscopy found that most (70\%) A. marginale inclusion bodies showed changes such as vacuolization and chromatin condensation after exposure to oxytetracycline but all others were morphologically normal. This finding suggests that the action of this antibiotic is dependent of time and its concentration is required to be above the minimum inhibitory concentration to have an effect on the pathogenic agent.

The present study assessed the effectiveness of enrofloxacin for the treatment of cattle experimentally infected with a virulent A. marginale strain. Enrofloxacin is a broad-spectrum bactericidal antibiotic that affects bacterial DNA metabolism through topoisomerase II and IV enzymes. The observed pharmacokinetics of enrofloxacin indicates that high plasma concentrations are achieved in a short period of time. This rapid reaction time results in a faster response (KAARTINEN et al., 1997). In this study we found a significant reduction of $A$. marginale rickettsemia 24 hours after treatment with a single dose $\left(7.5 \mathrm{mg} \cdot \mathrm{kg}^{-1}\right)$ of enrofloxacin.
This rapid reduction of $A$. marginale rickettsemia associated the changes observed in the membrane of Anaplasma inclusions after exposure to enrofloxacin (COETZEE et al., 2009) suggests that this product has a rickettsicidal effect.

The literature has described enrofloxacin treatment of A. marginale infection using two doses at different frequencies and dosages. Guglielmone et al. (1996) treated animals with two doses of $10 \mathrm{mg} \cdot \mathrm{kg}^{-1}$ for two consecutive days when rickettsemia levels ranged from 3 to $10 \%$. Coetzee and Apley (2006) evaluated the efficacy of two doses of enrofloxacin at $12.5 \mathrm{mg} \cdot \mathrm{kg}^{-1}$ with 48 hours intervals in splenectomized calves when rickettsemia was greater than $25 \%$. All these studies found a significant reduction of $A$. marginale rickettsemia. However, in our study there was no significant difference $(p>0.05)$ in the reduction of rickettsemia when G1 and G2 were compared. This result indicates that the use of either one or two doses of $7.5 \mathrm{mg} \cdot \mathrm{kg}^{-1}$ of enrofloxacin does not affect the development of $A$. marginale rickettsemia.

Anemia is the main clinical manifestation of anaplasmosis. In this disease the patent period (PP) is the time from the beginning of PCV decline up to the restoration of physiological minimum PCV (24\%) (MEYER et al., 1995). In the present experiment, the animals treated with enrofloxacin had a PP of 14 days while those treated with oxytetracycline had a PP of 21 days. The pathogenesis of anemia in anaplasmosis is related to the destruction of red blood cells in the monocytic phagocytic system (MPS), mainly in the spleen. In acute infections, there is a close correlation between rickettsemia and anemia. This correlation indicates that in this early phase there is only destruction of red blood cells parasitized by Anaplasma (AJAYI et al., 1978). Later, through an autoimmune mechanism, autoantibodies are produced inducing the removal of parasitized and unparasitized erythrocytes (RISTIC et al., 1972). Thus, in the early phase of infection, enrofloxacin reduces the removal of erythrocytes by MPS. This effect contributes to an earlier recovery of PCV.

On the first day of treatment (Day 0), the animals inoculated with $A$. marginale showed increased body temperatures (Table 1 ). Animals treated with enrofloxacin (G1 and G2) had their body temperatures back to normal by Day 4 and 5, respectively, posttreatment and in those treated with oxytetracycline normal body temperatures were seen by Day 11 . This finding has a direct association with rickettsemia. It confirms that the groups treated with enrofloxacin had a more rapid reduction of rickettsemia 
and a shorter period of hyperthermia than those who received oxytetracycline. The return to a normal body temperature is important for animal recovery with reduced apathy and increased food and water intake.

In conclusion, the administration of a single dose of enrofloxacin (7.5 mg. $\mathrm{kg}^{-1}$ ) was effective for the treatment of acute anaplasmosis. Enrofloxacin was more effective than oxytetracycline due to its better control of rickettsial infections caused by $A$. marginale and faster clinical recovery.

\section{References}

Ajayi SA, Wilson AJ, Campbell RSF. Experimental bovine anaplasmosis:clinico-pathological and nutritional studies. Res Vet Sci 1978; 25: 76-81.

Bastos CV, Passos LMF, Facury-Filho EJ, Rabelo EM, De La Fuente J, Ribeiro MFB. Protection in the absence of exclusion between two Brazilian isolates of Anaplasma marginale in experimentally infected calves. Vet J 2010; 186: 374-378. PMid:19837622. http://dx.doi. org/10.1016/j.tvjl.2009.09.013

Coetzee JF, Apley MD. Efficacy of enrofloxacin against severe experimental Anaplasma marginale infections in splenectomized calves. Vet Therapeut 2006; 7: 319-328.

Coetzee JF, Kocan KM, Higgins JJ, Apley MD, Jones DE. Ultrastructural and fluorochromatic changes of Anaplasma marginale exposed to oxyoxytetracycline, imidocarb and enrofloxacin in short-term erythrocyte cultures. Vet Microbiol2009; 136: 45-53. PMid:19054634. http://dx.doi. org/10.1016/j.vetmic.2008.10.014

Corrier DE, Guzman S. The effect of natural exposure to Anaplasma marginale and Babesia infections on native calves in an endemic area of Colombia. Trop Anim Health Prod 1977; 9: 47-51. PMid:562010. http:// dx.doi.org/10.1007/BF02297391

Instituto Interamericano de Cooperação para a Agricultura - IICA. Técnicas para el Diagnostico de Babesiosis y anaplasmosis. San Jose, Costa Rica: IICA; 1987.
Guglielmone AA, Anziani OS, Mangold AJ, Volpogni MM, Vogel A. Enrofloxacin to control Anaplasma marginale infections. Ann N Y Acad Sci 1996; 791: 471-472. PMid:8784531. http://dx.doi. org/10.1111/j.1749-6632.1996.tb53557.x

Jones EW, Kliener IO, Norman BB, Brock WE. Anaplasma marginale infection in young and aged cattle. Am J Vet Res 1968; 29: 535-544. PMid:5688978.

Kaartinen L, Pyorala S, Moilanen M, Raisanen S. Pharmacokinetics of enrofloxacin in newborn and one-week-old calves. J Vet Pharmacol Therapeut 1997; 20: 479-482. PMid:9430772. http://dx.doi. org/10.1046/j.1365-2885.1997.00100.x

Meyer DJ, Coles EH, Rich LS. Medicina de laboratório veterinária Interpretação e diagnóstico. SãoPaulo: Roca Ltda; 1995.

Palmer GH. Anaplasma vaccine. In: Wright IG. Veterinary Protozoan and Hemoparasite Vaccines. Boca Raton: CRC Press; 1989. p. 1-25.

Ribeiro MFB, Reis R. Exposiçấo natural de bezerros, em área endêmica de Anaplasma marginale, de Minas Gerais. Arq Esc Vet UFMG 1981;33: 63 66.

Ristic M, Lykins JD, Morris HR. Anaplasmosis: opsonins and hemagglutinins in etiology of anemia. Exp Parasitol 1972; 31: 2-12. http://dx.doi.org/10.1016/0014-4894(72)90041-0

Roby TO, Gates DW, Mott LO. Comparative susceptibility of calves and adult cattle to bovine anaplasmosis. Am J Vet Res 1961; 22: 982-985. PMid:14492965.

Schilf EA. Bovine anaplasmosis can be controlled. J Am Vet Med Assoc 1971; 159: 1531-1533.

Scholar EM, Pratt WB. Bacteriostatic inhibitors of protein synthesis: oxytetracyclines. In: The Antimicrobial Drug. $2^{\text {nd }}$ ed. New York: Oxford University Press; 2000. p. 184-199.

Yeruham I, Braverman Y. The transmission of Anaplasma marginale to cattle by blood-sucking artthropods. Ref Vet 1981; 38:37-44. 